\title{
Late Permian ichthyofauna from the North-Sudetic Basin, SW Poland
}

\author{
Darja Dankina, Andrej Spiridonov, Paweł Raczyński, and Sigitas Radzevičius \\ Acta Palaeontologica Polonica 66 (3), 2021: s047-s057 doi:https://doi.org/10.4202/app.00839.2020
}

The late Permian time was a transformative period before the most severe mass extinction known. Even though fishes constitute a key component of marine ecosystems since the Silurian, their biogeographic patterns during the late Permian are currently insufficiently known. The new ichthyofaunal material described here comes from the southeastern part of the Zechstein Basin, from the calcareous storm sediments alternating with marls, which were deposited in less energetic conditions. Chondrichthyans and osteichthyans are reported here for the first time from the Nowy Kościół quarry in the SW Poland. The assemblage consists of various euselachian dermal denticles, actinopterygian scales and teeth, and isolated hybodontoid tooth putatively assigned as extremely rare ?Gansuselache sp. from the Permian. The diverse actinopterygian tooth shapes show significant ecological differentiation of fishes exploring sclerophagous, durophagous, and herbivory modes of feeding in the given part of the Zechstein Basin suggesting the presence of complex ecosystems even in hyper-saline conditions of an epicontinental sea.

Key words: Euselachii, Actinopterygii, teeth, scales, trophic groups, Permian, Zechstein, Poland.

Darja Dankina [darja.dankina@gmail.com], Andrej Spiridonov [s.andrej@gmail.com ], and Sigitas Radzevičius [sigitas.radzevicius@gf.vu.lt], Department of Geology and Mineralogy, Vilnius University, M.K. Čiurlionio st. 21/27, LT03101, Vilnius, Lithuania. Paweł Raczyński [pawel.raczynski@uwr.edu.pl], Department of Physical Geology, Institute of Geological Sciences, University of Wrocław, Pl. Maksa Borna 9, 50-205 Wrocław, Poland.

This is an open-access article distributed under the terms of the Creative Commons Attribution License (for details please see creativecommons.org), which permits unrestricted use, distribution, and reproduction in any medium, provided the original author and source are credited. 
For Full text $(1,076.5 \mathrm{kB})$ 